\title{
Reduction of mechanical interactions with the use of a rubber composite
}

\author{
Przemysław Palacz ${ }^{*}$, Maciej Major and Izabela Adamczyk \\ Czestochowa University of Technology, Faculty of Civil Engineering, Akademicka 3 Street, 42-200 \\ Czestochowa, Poland
}

\begin{abstract}
The paper presents the results of research on the reduction of mechanical interactions of the composite produced from components resulting from the recycling of used car tires and plastic bottles (i.e. polyethylene terephthalate, colloquially called PET). Composite samples for testing were made with three thicknesses of mixtures rubber granules and PET flakes. The whole was joined together with an epoxy resin and formed into the shape of discs, which were then subjected to mechanical interactions to determine the damping properties depending on the thickness of the considered samples. The samples were subjected to evaluation on the author's measuring stand. Obtained results of the research indicated that the developed composite well suppresses mechanical interactions resulting from dynamic interactions involving vibrations or vibrations in the analyzed frequency range. The developed composite can be used as a contribution to use in building materials that reduce mechanical interactions.
\end{abstract}

\section{Introduction}

Building materials commonly used in residential and industrial construction are subject to constant changes, aimed at finding more and more modern, energy-efficient and inexpensive construction and material solutions that give greater possibilities of application in various construction areas [1]. Considering environmental protection, proper management of waste management, as well as the comfort of human life, search is being carried out in the area of new ways to obtain a building material made on the basis of raw materials obtained from recycling. Thanks to waste management, it is possible to protect the environment, use cheaper raw materials or raw materials as a substitute for a less costly, faster and more effective material solution. In this article, a rubber composite is analyzed, developed as a product resulting from the recycling of car tires and PET, which was made from the recycling of plastic bottles. The developed rubber composite well absorbs vibrations and other mechanical influences as well as the propagation of acoustic waves. Rubber and PET flakes are combined with each other using a synthetic resin. 


\subsection{Rubber-based composites}

Rubber is a vulcanization product, made of natural and synthetic rubber, as well as other additives having in its composition 3\% sulfur and other admixtures. It is the main component of car tires, which after a period of operation are subjected to a recycling process and transformed, for example, into composites. Rubber is a product harmful to the natural environment, and its storage in larger quantities is a serious fire hazard. Therefore, the rubber is recycled, resulting in different fractions. Considering the size of rubber pellets, larger fractions are suitable for playground surfaces and are used for the construction of sports track surfaces, while smaller fractions are used to create, for example, car mats [2-5].

Rubber is characterized by very good damping properties; therefore, it is a material that is widely used for damping mechanical interactions resulting from the vibrations of the medium particles associated with the propagation of the disorder or the propagation of the wave. Rubber as a material can be used as an admixture, in the form of aggregate dosed by volume to concrete, however, obtaining damping properties is more beneficial based on a composite, where more than $50 \%$ is a rubber charge. Rubber-based composites are an excellent vibro-isolator of mechanical interactions. As a result, they reduce the impact of various dynamic interactions. They are also characterized by significant internal damping, can absorb sounds and exhibit very good form elasticity. In comparison to steel, for example, the rubber does not corrode, and is resistant to fatigue and abrasion [6-12].

\section{Research stand and research methodology}

The electrodynamic exciter K2007E01 Mini SmartShakerTM TMS The Modal Shop, inc. was used for the study, which was placed on a tripod made of C-section (100), which was welded to a $30 \mathrm{~mm}$ thick sheet of steel. The exciter was mounted on a rail enabling its free movement in the vertical direction to adjust to the appropriate thickness of the sample. On the basis of a distance of $30 \mathrm{~mm}$ from the sample, accelerometers were placed to compare the acceleration with the accelerometer mounted at the exciter, which made it possible to determine the damping value for the sample under test. Measurements were made for three frequencies: 5, 10 and $20 \mathrm{~Hz}$. The reading was obtained from accelerometers connected with each other using DEWESoft ${ }^{\circledR}$. The diagram of the measurement station and the location of the sensors are shown in Fig. 1. 

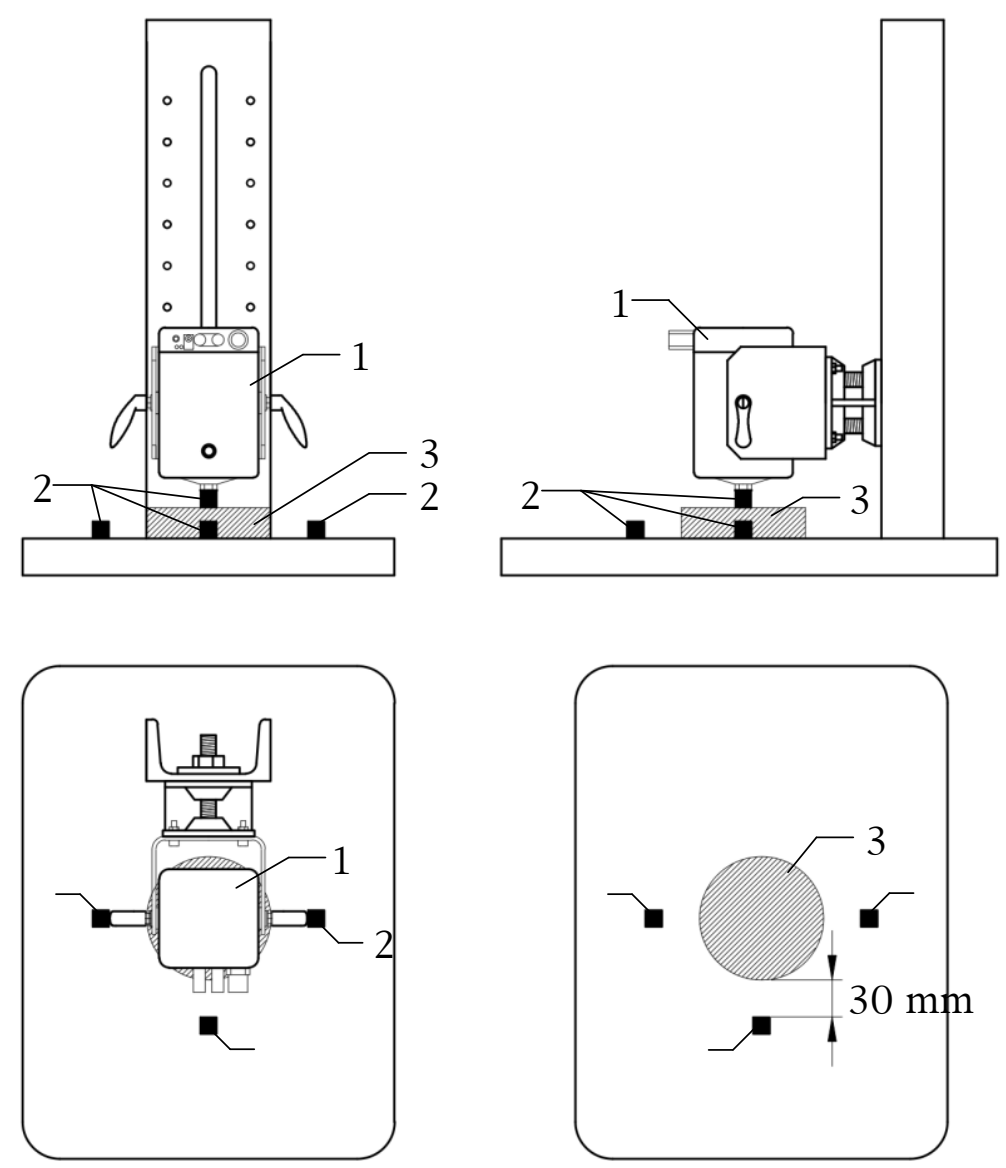

Fig. 1. Diagram of the measuring stand. 1 - electrodynamic exciter; 2 - accelerometer; 3 - a sample.

Below (photo 1) is a view of the author's measuring stand to determine the damping properties (reducing mechanical interactions) for the developed composite compound.

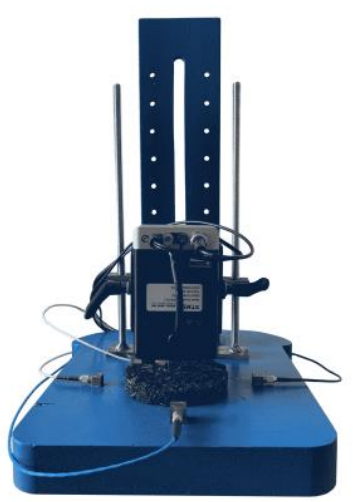

Photo 1. View of the measuring stand.

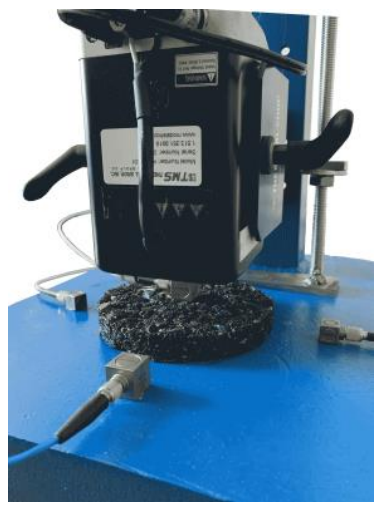

Photo 2. View of the measuring stand. 


\section{Rubber compound - composition and execution of samples}

The rubber composite considered in this work was made of the following components:

- $57 \%$ - had a rubber SBR, fraction below $1 \mathrm{~mm}$, coming from car tires,

- $29 \%$ - PET flakes, originating from plastic food packaging,

- $14 \%$ - epoxy resin, a binder for the materials mentioned above.

a)

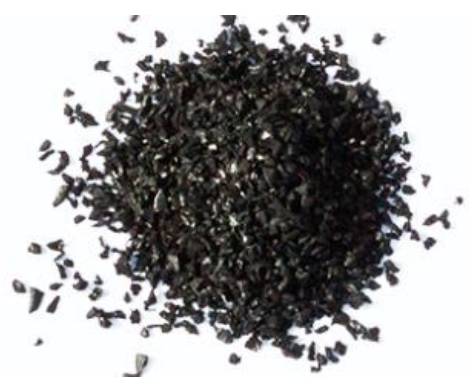

b)

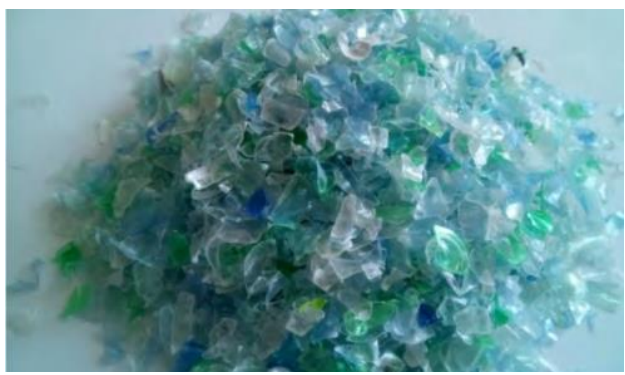

Fig. 2. Materials used to make the composite: a) Material derived from the recycling of car tires rubber granulate with a fraction below $1 \mathrm{~mm}$; b) Material from recycled plastic bottles - colored PET flakes

In the previously prepared form - a disc with a diameter of $100 \mathrm{~mm}$, mixed composite components were placed and left to obtain the target performance parameters. Samples with three thicknesses were used for the assessment in accordance with Table 1.

Table 1. Markings of samples and their thickness.

\begin{tabular}{|c|c|}
\hline Markings of samples & Thickness of the sample \\
\hline Sample 1 & $15 \mathrm{~mm}$ \\
\hline Sample 2 & $20 \mathrm{~mm}$ \\
\hline Sample 3 & $25 \mathrm{~mm}$ \\
\hline
\end{tabular}

Below (photo 3) are presented photos of samples for determination of damping properties (reducing mechanical interactions) for the developed composite mixture.

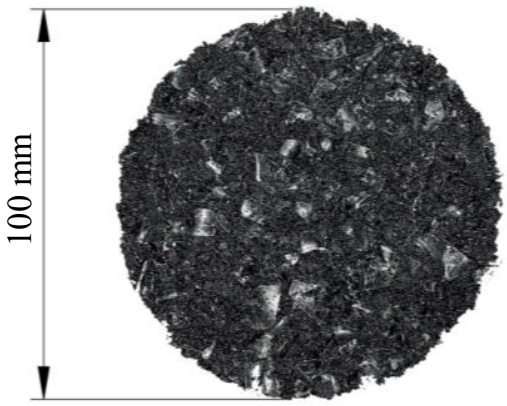

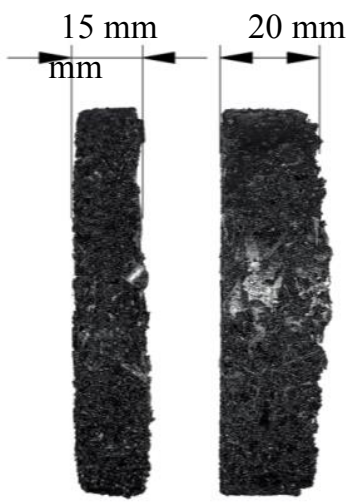

Sample 1 Sample 2

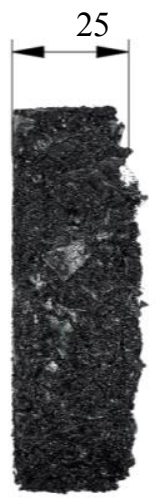

Sample 3

Photo 3. Samples produced with three thicknesses 


\section{Results and discussion}

The diagrams below present a comparison of average results from acceleration measurements from three accelerometers placed at a distance of $30 \mathrm{~mm}$ from the tested sample. Measurements were made at different frequencies: 5, 10 and $20 \mathrm{~Hz}$. The graphs show that the acceleration during the test is smaller for a thicker sample, which indicates that the attenuation decreases with the thickness of the material being tested.

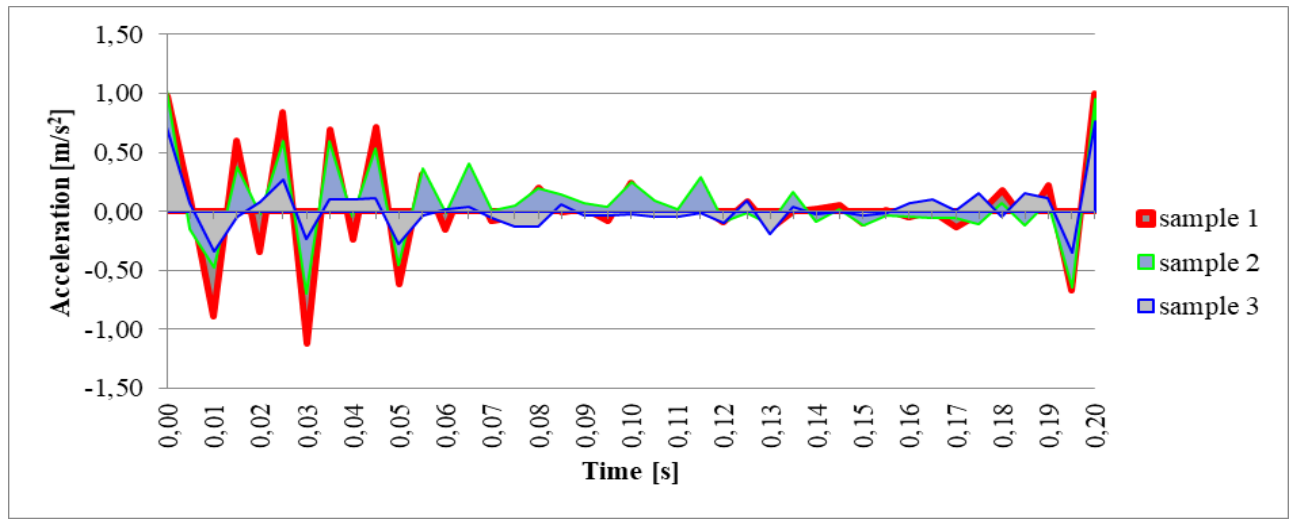

Fig. 2. Comparison of acceleration in time between samples 1, 2 and 3 at $5 \mathrm{~Hz}$.

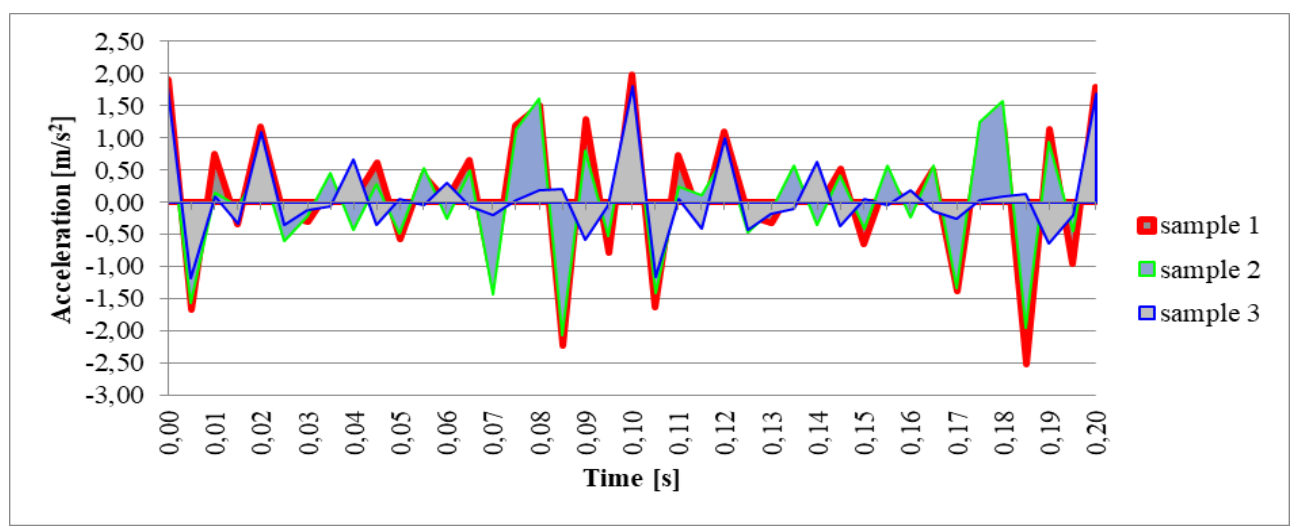

Fig. 3. Comparison of acceleration in time between samples 1,2 and 3 at $10 \mathrm{~Hz}$.

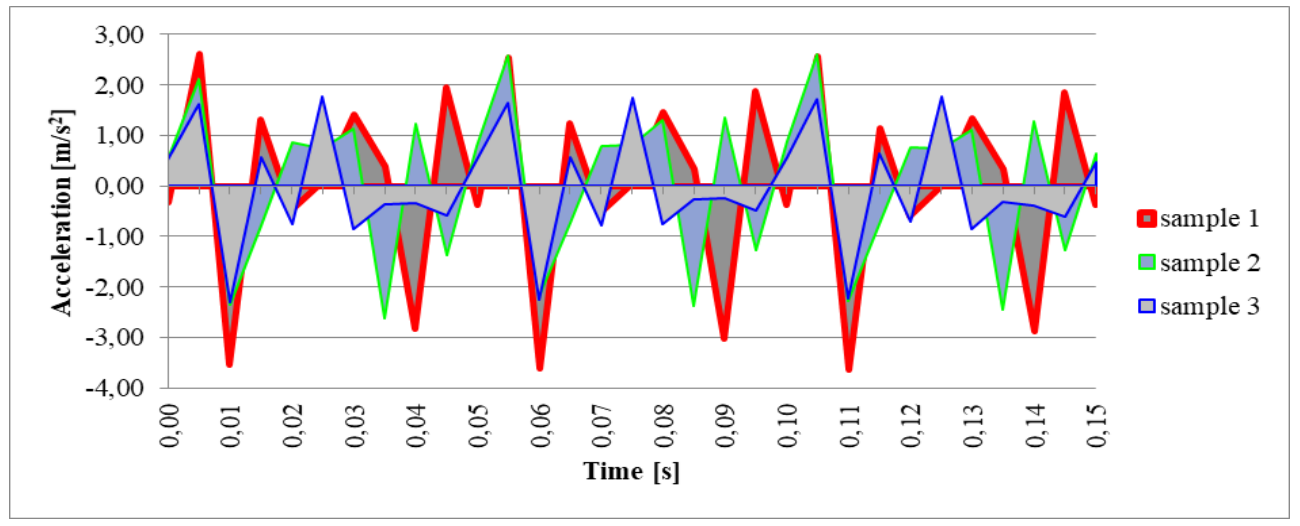

Fig. 4. Comparison of acceleration in time between samples 1, 2 and 3 at $20 \mathrm{~Hz}$. 
From the analysis of the above diagrams, it can be noticed that the frequency influences the damping value, i.e. the attenuation at 5 and $20 \mathrm{~Hz}$ is close to each other, while the attenuation at $10 \mathrm{~Hz}$ has the highest value. In total, all attenuation values have been found in Table 2.

Table 2. Damping values depending on thickness and frequency.

\begin{tabular}{|c|c|c|c|c|}
\hline \multirow{2}{*}{$\begin{array}{c}\text { Markings of } \\
\text { samples }\end{array}$} & \multirow{2}{*}{$\begin{array}{c}\text { Thickness of the } \\
\text { sample }\end{array}$} & \multicolumn{3}{|c|}{ Damping for respective frequencies } \\
\cline { 3 - 5 } & $\mathbf{5} \mathbf{~ H z}$ & $\mathbf{1 0 ~} \mathbf{~ z z}$ & $\mathbf{2 0} \mathbf{~ H z}$ \\
\hline Sample 1 & $15 \mathrm{~mm}$ & $7.15 \%$ & $10.36 \%$ & $7.41 \%$ \\
\hline Sample 2 & $20 \mathrm{~mm}$ & $11.70 \%$ & $13.35 \%$ & $12.99 \%$ \\
\hline Sample 3 & $25 \mathrm{~mm}$ & $12.87 \%$ & $14.63 \%$ & $13.59 \%$ \\
\hline
\end{tabular}

\section{Conclusions}

Based on the conducted tests, the proposed rubber composite very well fulfills its damping properties in the range between 5 and $20 \mathrm{~Hz}$, with the most effective damping properties occur at $10 \mathrm{~Hz}$. At $20 \mathrm{~Hz}$, the damping values are comparable to those at $5 \mathrm{~Hz}$. These three frequencies are the most adequate from the point of view of the hazard considering the impact on structures. The frequency criteria in which the target work of the composite material to be made have been accepted. Based on the research of the rubber composite developed here, it can be clearly stated that the rubber composite made based on synthetic resin, despite the high stiffness of the binder adhesive (glue) reinforced with PET flakes, very well suppresses mechanical interactions.

It should be remembered that the components resulting from the recycling of car tires are widely used in construction to produce various building materials. This is due to the need to use the physical properties of the rubber. In the case of waste resulting from the processing of polyethylene terephthalate, the possibility of reusing it also as a raw material used in the production of building materials is used. Skillful management of these wastes undoubtedly contributes to the protection of the environment. In addition, rubber waste and PET flakes can be used to produce composites based on them, used to reduce mechanical interactions, including also considering the hydroelasticity of the discussed materials $[5,13]$.

\section{References}

1. Major M., Major I., Ekologiczny kompozyt ścienny betonowo-gumowy, Budownictwo o Zoptymalizowanym Potencjale Energetycznym 2016, 1(17), 61-66.

2. Adamczyk-Królak I., Guma i politereftalan etylenu z recyklingu - składniki materiałów budowlanych, Zeszyty Naukowe Politechniki Częstochowskiej nr 24 (2018), 9-12.

3. Parasiewicz W., Pyskło L., Guma w samochodach - odzysk i recykling, Recykling 2005, 11, 10-12.

4. Niemiro J., Analiza i wykorzystanie dźwiękochłonnych właściwości granulatu gumowego pozyskanego z recyklingu, Zeszyty Naukowe Politechniki Częstochowskiej 2016, seria Budownictwo 22, 257-264. 
5. Major M., Różycka J., Gumopochodne materiały hipersprężyste - omówienie i kryteria praktycznego zastosowania, Zeszyty Naukowe Politechniki Częstochowskiej 2011, seria Budownictwo 17, 134-145.

6. Major M., Major I., Wykorzystanie odpadów gumowych w budownictwie zrównoważonym, Budownictwo o Zoptymalizowanym Potencjale Energetycznym 2014, 2(14), 38-45.

7. Wprowadzenie do recyklingu opon: 2004, Stowarzyszenie Przemysłu Gumowego EKOGUMA, Piastów, wrzesień 2004.

8. Horodecka R., Kalabińska M., Piłat J., Radziszewski P., Sybilski D., Wykorzystanie zużytych opon samochodowych w budownictwie drogowym, Studia i Materiały, zeszyt 54, IBDiM, Warszawa 2002.

9. Sybilski D., Zastosowanie odpadów gumowych w budownictwie drogowym, Przegląd Budow- lany 2009, 5, 37-44.

10. Pyskło L., Parasiewicz W., Odzysk i recykling wyrobów gumowych, Recykling 2004, 11, p. 52.

11. Major M., Major I., Różycka J., Zastosowanie warstwowego kompozytu gumowego w celu redukcji oddziaływań dynamicznych na konstrukcje stalowe, Budownictwo i Architektura 2014, 13(2) 275-282.

12. Kosiński S., Fale sprężyste w gumo podobnych kompozytach warstwowych, Monografie Politechniki Łódzkiej, Łódź 2007.

13. Major, I.: 'Numerical analysis of wave phenomena in hyperelastic Mooney - Rivlin and Zahorski materials', Civil and environmental engineering, Scientific - Technical Journal, 2014, 10, (1), pp. 110-119. 